\title{
Role of PKC $\zeta$ translocation in the development of type 2 diabetes in rats following continuous glucose infusion
}

\author{
Jing-fang Zhang ${ }^{1,2}$ \\ Jing-ping Ou Yang ${ }^{1}$ \\ Guang-hao Wang ${ }^{1,3}$ \\ Zhengyuan $\mathrm{Xia}^{4}$ \\ Sheng Zhong Duan ${ }^{5}$ \\ Yong $\mathrm{Wu}^{6 *}$ \\ ${ }^{1}$ Department of Pathophysiology, \\ Medical College, Wuhan University, \\ Wuhan, Hubei, China \\ ${ }^{2}$ Medical School, Jingchu University \\ of Technology, Jingmen, Hubei, China \\ ${ }^{3}$ Department of Internal Medicine, \\ The Second People's Hospital of \\ Jingmen City, Jingmen, Hubei, China \\ ${ }^{4}$ Department of Anesthesiology, \\ Research Centre of Heart, Brain, \\ Hormone and Healthy Aging, \\ University of Hong Kong, Hong Kong \\ SAR, China \\ ${ }^{5}$ Nephrology Division, Department of \\ Internal Medicine, University of \\ Michigan Medical School, Ann Arbor, \\ MI, USA \\ ${ }^{6}$ Department of Biochemistry, \\ University of California, Riverside, \\ CA, USA
}

*Correspondence to: Yong Wu, Department of Biochemistry, University of California, 900 University Ave., Riverside, CA 92521, USA.

E-mail: yong.wu@ucr.edu

Received: 6 June 2009

Revised: 1 November 2009

Accepted: 2 November 2009

\begin{abstract}
Aim We investigated the molecular mechanisms of hyperglycaemia-induced insulin resistance and type 2 diabetes in rats receiving a continuous glucose infusion (GI).

Methods Female Wistar rats were infused with either $2.8 \mathrm{~mol} / \mathrm{L}$ glucose or saline $(2 \mathrm{~mL} / \mathrm{h})$ for durations varying from 0 to 15 days. Blood samples were analysed daily to determine glucose and insulin dynamics. Subsets of animals were sacrificed and solues muscles were extracted for determination of protein expression, subcellular location, and activities of insulin-signalling proteins.
\end{abstract}

Results Rats accommodated this systemic glucose oversupply and developed insulin resistance on day 5 (normoglycaemia/hyperinsulinaemia) and type 2 diabetes on day 15 (hyperglycaemia/normoinsulinaemia). The effect of GI on protein kinase $\mathrm{C} \zeta$ (PKC $\zeta$ ) activity was independent of changes in phosphatidylinositol 3-kinase activity, and occurred in parallel with an increase in PDK1 activity. Activated PKC $\zeta$ was mainly located in the cytosol after 5 days of GI that was coincident with the translocation of GLUT4 to the plasma membrane, and normoglycaemia. After 15 days of GI, PKC $\zeta$ translocated from the cytosol to the plasma membrane with a concomitant decrease in PDK1 activity. This caused an increase in the association between $\mathrm{PKC} \zeta$ and PKB and a decrease in PDK1-PKB reactions at the plasma membrane, leading to reduced PKB activity. The activity of PKC $\zeta$ per se was also compromised. The PKC $\zeta$ and $\mathrm{PKB}$ activity reduction and the blunted insulin-stimulated GLUT4 translocation eventually led to hyperglycaemia and diabetes.

Conclusion Translocation of $\mathrm{PKC} \zeta$ may play a central role in the development of type 2 diabetes. Copyright @ 2009 John Wiley \& Sons, Ltd.

Keywords insulin resistance; type 2 diabetes; phosphatidylinositol-dependent kinase 1 ; protein kinase $\mathrm{B}$; protein kinase $\mathrm{C} \zeta$; translocation

\section{Introduction}

Insulin resistance is a major pathogenic stage in the development of type 2 diabetes [1]. In humans and rodents, skeletal muscle is the most important tissue for the maintenance of balanced postprandial glucose homeostasis: about $80 \%$ of insulin-stimulated glucose uptake is accounted for by muscle [2,3]. 
Insulin increases glucose uptake in muscle by eliciting translocation of the protein GLUT4 from an intracellular storage site to both the plasma membrane (PM) and the transverse $(\mathrm{T})$-tubules through a complex signalling cascade $[4,5]$. Impaired GLUT4 translocation is linked to reduced glucose utilization in skeletal muscle of insulin resistant and type 2 diabetic humans [6,7]. Considerable work has been done to elucidate the molecular mechanisms regulating GLUT4 translocation. The general consensus is that activation of phosphatidylinositol 3kinase (PI 3-kinase) via its interaction with insulin receptor substrates (IRSs) [8] plays an essential role $[9,10]$. In addition, downstream of PI 3-kinase, two serine/threonine kinases, namely $\mathrm{PKB} /$ Akt and atypical protein kinase $\mathrm{C}$ (PKC) $\zeta / \lambda$ have been implicated as major transducer proteins of glucose transport in response to insulin in different cell models $[11,12]$. However, it is now clear that GLUT4 translocation can be activated by different agents by a mechanism not involving the proximal steps of the insulin-signalling cascade. For example, bypassing the initial insulin signal transduction steps, hyperosmolarity can stimulate GLUT4 translocation and glucose transport through activation of a common convergent signal transduction step downstream of and/or in parallel to PI 3-Kinase/Akt [13,14].

Hyperglycaemia is a major factor contributing to the development of peripheral insulin resistance in patients with both type 1 and type 2 diabetes [15]. Restoration of glycaemia normalizes insulin action on glucose transport in isolated skeletal muscle from type 2 diabetic subjects [16], and in animal models of diabetes [17]. Thus, hyperglycaemia appears to have a profound impact on insulin action through a desensitization of the insulin-signalling transduction, but how it impairs insulin action is largely unknown. Studies [18,19] show that hyperglycaemia impairs insulin sensitivity and insulinstimulated phosphorylation/activation of $\mathrm{Akt} / \mathrm{PKB}$ in the liver of Zucker diabetic fatty rats. Also insulininduced Akt/PKB activation is reduced in skeletal muscles incubated in medium containing glucose at high concentration, without alteration of PI 3-kinase activity [20]. Furthermore, insulin-induced Akt/PKB activation is reported to be decreased in skeletal muscles of the diabetic Goto-Kakizaki rat $[17,21]$. Thus, the reduced activation of Akt/PKB is a candidate for the defects leading to insulin resistance caused by hyperglycaemia in both the liver and the skeletal muscle.

Interestingly, hyperglycaemia, just like hyperosmolarity, in addition to its inhibiting effect on PKB and GLUT4 translocation, could stimulate glucose uptake directly. Studies in diabetic patients revealed that hyperglycaemia leads to increased glucose uptake in skeletal muscle in a glucose concentration-dependent manner [22], but the underlying mechanism is poorly understood. Studies on cultured myotubes and isolated rat skeletal muscle tissues have shown that short-term hyperglycaemia is an insulin-independent inducer of GLUT4 translocation [23] that involves PKC activation. Moreover, studies [23,24] show that enhanced PKC activity is involved in mediating insulin resistance. Taken together, these in vitro studies indicate that acute increases in glucose activate PKC, which on one hand induces insulin-independent glucose uptake and, on the other hand, could mediate insulin resistance.

The focus of the current study is on two members of the AGC kinase super family: PKB/Akt and PKC $\zeta$. $\mathrm{PKC} \zeta$ is the major atypical PKC in skeletal muscles and adipose tissues of humans, monkeys, and rats. It is considered as a negative regulator of $\mathrm{PKB}$ [25] and is required for insulin-stimulated glucose transport. To study the role of $\mathrm{PKB}$ and $\mathrm{PKC} \zeta$ in the development of insulin resistance and diabetes in vivo, we used the glucose-infused rat model originally developed by Leahy et al. [26]. In this model, continuous systemic glucose oversupply induces insulin resistance (normoglycaemia/hyperinsulinaemia) and then overt type 2 diabetes (hyperglycaemia/normoinsulinaemia). This model mimics the pathobiochemical changes in humans with nutrient oversupply and subsequent insulin resistance associated with increased lipid accumulation in adipose tissue and skeletal muscle. Using this model we were able to observe in the hindlimb muscle dynamic changes in insulin-signalling molecules such as PDK1, PKC $\zeta$, PKB, and GLUT4 activities as well as their localization in the development of insulin resistance and type 2 diabetes.

\section{Research design and methods}

\section{Materials}

Reagents for sodium dodecyl sulfate-polyacrylamide gel electrophoresis and immunoblotting were obtained from Biovision (Palo Alto, CA, USA) and the apparatus used was from Bio-Rad (Richmond, CA, USA). Protein A/GSepharose, Tris, NP-40, and nitrocellulosemembranes were obtained from Sigma Chemical Co. (St Louis, MO, USA). Monoclonal anti-Akt/PKB antibodies were purchased from Santa Cruz Biotechnology, Inc. (Santa Cruz, CA, USA). The anti-rat carboxy-terminal IRS-1 antibody (Clone 8-63) was from NeoMarkers (Fremont, CA, USA). Anti-PKC $\zeta$ antibody and the antibody to the p85 Subunit of PI-3-Kinase ( $\alpha$ p85) was from Upstate Biotechnology (Lake Placid, NY, USA). The monoclonal antibody to PDK1 was from Transduction Laboratories (Lexington, UK). The monoclonal anti-rat GLUT4 antibody was from R\&D Systems, Inc. (Minneapolis, AL, USA). Myristoylated $\mathrm{PKC} \zeta$ pseudosubstrate peptide inhibitor was from Biomol (Plymouth Meeting, PA, USA) and SH-6 from Kamiya Biomedical Co. (Seattle, WA, USA). Enhanced Chemiluminescence detection reagents were from KPL (Gaithersburg, MA, USA). $\left(\gamma-{ }^{32} \mathrm{P}\right) \mathrm{ATP}$ was from Amersham (Aylesbury, UK). The Perfuser syringe pump was purchased from Perfusor B. Braun (Melsungen, Germany). All other chemicals used were of the highest analytical grade. 


\section{Animals}

The Institutional Animal Experimentation Ethics Committee approved all surgical procedures performed in this study, which followed established principles of laboratory animal care (NIH publication no. 85-23, revised 1985). Female Wistar rats weighing about $280 \mathrm{~g}$ were purchased from the Experimental Animal Center of Wuhan University and were kept at $22^{\circ} \mathrm{C}$ with a $12: 12 \mathrm{~h}$ light-dark cycle and a relative humidity of 55-60\% during the whole experimental period. The rats had free access to water and standard chow pellet diet.

\section{Prolonged glucose infusion into conscious rats}

Glucose infusion (GI) was performed as previously described [27,28]. The age-matched rats undergoing the infusion studies were anesthetized with Ketamine (125 mg/100 g body weight, i.p.). Surgery was performed under sterile conditions. A 1-cm long incision was made between the sternum and the mandible; the right external jugular vein was then exposed by blunt dissection and dissected free of the surrounding connective tissue. The jugular vein was ligated cranially and the vein was incised distal to the ligature. A catheter filled with 50 IU heparin in $0.9 \%$ saline was introduced into the vein so that its tip laid just cranial to the right atrium. The catheter was then anchored by double ligation. The free end of the catheter was routed dorsally subcutaneous to the back of the neck. A second incision was then made and the catheter was externalized and fixed using an anchoring device. The incision was then sutured. The externalized catheter was routed through a flexible spring tether to a swivel and connected by an oscillating arm to a Perfusor syringe pump. The rats were housed singly in a metabolic cage and allowed to recover for $48 \mathrm{~h}$ after which $\mathrm{GI}(2.8 \mathrm{~mol} / \mathrm{L}$ glucose) was started at a rate of $2 \mathrm{~mL} / \mathrm{h}$ (group GR) versus $77 \mathrm{mmol} / \mathrm{L}$ saline infusion at $2 \mathrm{~mL} / \mathrm{h}$ for controls (group C). Glucose and saline infusions were carried out at the same time. Blood samples were taken from the tail vein and glucose and insulin concentrations were determined as described [27].

\section{Muscle isolation and preparation}

After 5 or 15 days of continuous glucose or saline infusion, experiments were terminated by disconnecting the syringe pump. Rats were then immediately removed from the cage and then anesthetized by pentobarbital (100 mg/kg i.p.). The hind limb muscles were quickly excised before and $15 \mathrm{~min}$ after insulin injection $(5 \mathrm{U} / \mathrm{kg})$, dissected free of connective tissue and fat and chopped into small pieces. This step was carried out on ice. Chopped muscles were immediately frozen in liquid nitrogen and subsequently stored at $-70^{\circ} \mathrm{C}$ until further preparation.

\section{2-deoxyglucose uptake assay}

To investigate effects of $\mathrm{PKB}$ or $\mathrm{PKC} \zeta$ inhibition on glucose transport in skeletal muscle of glucose-infused rats after five days, we employed enzyme inhibition studies. Hindlimb soleus skeletal muscles were removed, blotted on gauze, and transferred to 25-mL flasks containing $2 \mathrm{~mL}$ of Krebs-Henseleit buffer (KHB) with $0.1 \%$ bovine serum albumen, $32 \mathrm{mM}$ mannitol, and $8 \mathrm{mM}$ glucose. The incubation studies of this muscle have been extensively described [29]. The flasks were incubated in a shaking water bath maintained at $30^{\circ} \mathrm{C}$ for $1 \mathrm{~h}$, and were continuously gassed with $95 \% \quad \mathrm{O}_{2} / 5 \% \quad \mathrm{CO}_{2}$. Muscles were initially incubated, respectively, in the presence or absence of myristoylated $\mathrm{PKC} \zeta$ peptide inhibitor (PS $\zeta$ ) $(40 \mu \mathrm{M})$ or SH-6 (5 M), an inhibitor of Akt (PKB) for $1 \mathrm{~h}$ prior to incubation under basal condition or stimulation with insulin $(13 \mathrm{nM})$ for $10 \mathrm{~min}$. The muscles were then transferred to flasks containing $2 \mathrm{~mL}$ of $\mathrm{KHB}$ with $0.1 \%$ bovine serum albumen, $40 \mathrm{mM}$ mannitol, $2 \mathrm{mM}$ pyruvate, and the same additions as in the previous incubation. The flasks were incubated for $10 \mathrm{~min}$ at $30^{\circ} \mathrm{C}$ to wash out glucose and the gas phase in the flasks was maintained at $95 \% \mathrm{O}_{2} / 5 \% \mathrm{CO}_{2}$. Following the above incubations, the muscles were rinsed by incubation in $\mathrm{KHB}-0.1 \%$ bovine serum albumen $-40 \mathrm{mM}$ mannitol with or without insulin for $10 \mathrm{~min}$ and blotted and transferred to flasks containing $1.5 \mathrm{~mL}$ of $\mathrm{KHB}$ with $1 \mathrm{mM}$ 2-deoxy-[1,2- $\left.{ }^{3} \mathrm{H}\right]$ glucose $(1.5 \mathrm{mCi} / \mathrm{mmol})$, and $39 \mathrm{mM}\left[1^{14} \mathrm{C}\right]$ mannitol $(8 \mu \mathrm{Ci} / \mathrm{mmol})$ and the same additions as in the previous incubation. The flasks were incubated at $30{ }^{\circ} \mathrm{C}$ for $20 \mathrm{~min}$ and continuously gassed with $95 \% \mathrm{O} 2 / 5 \% \mathrm{CO} 2$. Thereafter the muscles were frozen and stored at $-80^{\circ} \mathrm{C}$ until processed for measurement of 2-deoxyglucose (2-DOG) transport. Frozen muscles were dissolved and then processed, and the extracellular space and intracellular 2-DOG concentrations were determined as described previously [30]. Glucose transport activity is expressed as $\mu \mathrm{mol} / 20 \mathrm{~min} / \mathrm{mL}$ intracellular water.

\section{Skeletal muscle subcellular fractionation}

Cytosol and membrane fractions were separated as described [31]. Briefly, frozen samples were homogenized in a 10:1 volume to weight ratio of homogenization buffer [20 mM Tris $\mathrm{pH} 7.5,0.5 \mathrm{mM}$ ethylenediaminetetraacetic acid (EDTA), $0.5 \mathrm{mM}$ ethyleneglycol bis(2-aminoethyl-ether)teraacetic acid (EGTA), $25 \mu \mathrm{g} / \mathrm{mL}$ aprotinin, $25 \mu \mathrm{g} / \mathrm{mL}$ leupeptin, $10 \mathrm{mM} \mathrm{NaF}, 10 \%$ glycerol, $5 \mathrm{mM} \mathrm{MgCl} 2,0.5 \mathrm{mM}$ dithiothreitol] on ice using a glass on glass homogenizer. The sample was centrifuged for $20 \mathrm{~min}$ at $160000 \mathrm{~g}$ in an ultracentrifuge. The supernatant was collected as the cytosolic fraction. Half the original volume of homogenization buffer was added to the pellet, with $0.5 \%$ Triton $\mathrm{X}-100$. The sample was further homogenized on ice for 10-15 s and incubated on ice for $30 \mathrm{~min}$. The homogenate was then centrifuged 
at $160000 \mathrm{~g}$ for $20 \mathrm{~min}$. The resulting supernatant was collected as the PM fraction.

\section{PI 3-kinase activity}

Muscle pieces were immediately homogenized in a $10 \times$ volume of ice-cold buffer $A$ (in mM: 50 4-(2hydroxyethyl)-1-piperazineethanesulfonic acid (HEPES) (pH 7.5), $137 \mathrm{NaCl}, 1 \mathrm{MgCl}_{2}, 1 \mathrm{CaCl}_{2}, 10 \mathrm{Na}_{4} \mathrm{P}_{2} \mathrm{O}_{7}$, $50 \mathrm{NaF}, 2$ EDTA, $40 \beta$-glycerophosphate, $2 \mathrm{Na}_{3} \mathrm{VO}_{4}, 0.2$ phenylmethylsulfonyl fluoride (PMSF), and 1\% NP-40, $10 \%$ glycerol, and $2 \mu \mathrm{g} / \mathrm{mL}$ aprotinin) and centrifuged at $15000 \mathrm{~g}$ at $4{ }^{\circ} \mathrm{C}$ for $30 \mathrm{~min}$. Protein concentration was determined using a commercial assay kit (Bio-Rad). The supernatants containing equal amounts of protein were immunoprecipitated overnight at $4{ }^{\circ} \mathrm{C}$ with antiIRS-1 antibody or anti-phosphotyrosine antibody coupled to protein A Sepharose. The immunoprecipitates were collected and washed. PI 3-kinase activities in the immunoprecipitates were assayed as described [32].

\section{PDK1 activity}

A fragment of frozen muscle $(25-30 \mathrm{mg}$ ) was homogenized in $500 \mu \mathrm{L}$ of ice-cold buffer containing $50 \mathrm{mM}$ Tris (pH 8.0), 0.5\% Triton X-100, 1 mM EDTA, 1 mM EGTA, $50 \mathrm{mM} \mathrm{NaF}, 5 \mathrm{mM} \mathrm{Na}{ }_{4} \mathrm{P}_{2} \mathrm{O}_{7}, 10 \mathrm{mM} \beta$-glycerophosphate, $1 \mathrm{mM}$ sodium vanadate, $\mu \mathrm{M}$ microcystin, $20 \mathrm{mM}$ $\beta$-mercaptoethanol. Samples were solubilized by continuous stirring for $40 \mathrm{~min}$ at $4^{\circ} \mathrm{C}$ and centrifuged at $12000 \mathrm{~g}$ for $10 \mathrm{~min}$ at $4^{\circ} \mathrm{C}$. The supernatant was immunoprecipitated for $2 \mathrm{~h}$ at $4{ }^{\circ} \mathrm{C}$ with anti-PDK1 antibody coupled to protein $\mathrm{A} / \mathrm{G}$ Sepharose. The immune complex was washed and PDK1 activity was determined as described [33]. Radioactivity was counted using a Packard Tri-Card $2000 \mathrm{Ca}$ liquid scintillation counter.

\section{PKC $\zeta$ activity}

The remaining fragment of muscle $(25-30 \mathrm{mg})$ was homogenized in $600 \mu \mathrm{L}$ of ice-cold buffer containing $20 \mathrm{mM}$ of Tris/ $\mathrm{HCl}$ (pH 7.5), $250 \mathrm{mM}$ sucrose, $1.2 \mathrm{mM}$ EGTA, $20 \mathrm{mM} \beta$-mercaptoethanol, $1 \mathrm{mM}$ PMSF, $5 \mu \mathrm{g} / \mathrm{mL}$ leupeptin, $5 \mu \mathrm{g} / \mathrm{mL}$ aprotinin, $1 \mathrm{mM} \mathrm{Na} \mathrm{VO}_{4}, 1 \mathrm{mM}$ $\mathrm{Na}_{4} \mathrm{P}_{2} \mathrm{O}_{7}, 1 \mathrm{mM}$ NaF, $1 \%$ Triton-X 100, 0.5\% nonidet, and $2 \mu \mathrm{g} / \mathrm{mL}$ pepstatin. Samples were solubilized by continuous stirring for $30 \mathrm{~min}$ and centrifuged at $3000 \mathrm{~g}$ for $15 \mathrm{~min}$ at $4^{\circ} \mathrm{C}$. The supernatant was immunoprecipitated with anti-PKC $\zeta$ antibody coupled to protein $\mathrm{A} / \mathrm{G}$ Sepharose. The immune complex was washed and suspended in Buffer $B$ [50 mM Tris/HCl (pH 7.5), $5 \mathrm{mM} \mathrm{MgCl}_{2}, 100 \mu \mathrm{M} \mathrm{Na}_{3} \mathrm{VO}_{4}, 100 \mu \mathrm{M}$ $\mathrm{Na}_{4} \mathrm{P}_{2} \mathrm{O}_{7}, 1 \mathrm{mM} \mathrm{NaF}$, and $100 \mu \mathrm{M}$ phenylmethylsulfonyl fluoride]. Suspensions were then incubated for $8 \mathrm{~min}$ at $30^{\circ} \mathrm{C}$ in $100 \mu \mathrm{L}$ of Buffer $B$ containing $3-5 \mu \mathrm{Ci}$ of $\left[\gamma^{-32} \mathrm{P}\right] \mathrm{ATP}, 50 \mu \mathrm{M}$ ATP, $4 \mu \mathrm{g}$ of phosphatidylserine, and $40 \mu \mathrm{M}\left[{ }^{159}\right.$ Ser]PKC- $\varepsilon$ (AA153-164)-NH2 (Upstate
Biotechnology, Inc.), a preferred substrate for PKC- $\zeta$. Reactions were stopped by addition of $10 \mathrm{~mL}$ of $5 \%$ acetic acid. PKC $\zeta$ activity was determined as described [34].

\section{Akt/PKB activity}

PKB activity was measured as described by Kurowski et al. [20]. Muscles were homogenized in a $10 \times$ volume of ice-cold buffer $C$ (in mM: 20 Tris pH 7.5, 250 sucrose, $10 \mathrm{NaF}, 5$ EDTA, $1 \beta$-glycerophosphate, $2 \mathrm{Na}_{3} \mathrm{VO}_{4}, 0.2$ PMSF, $0.2 \mathrm{NH}_{4} \mathrm{MbO}_{4}, 1$ dithiothreitol, with $1 \%$ NP-40 and $2 \mu \mathrm{g} / \mathrm{mL}$ aprotinin) and centrifuged as for buffer $A$ (described above). The supernatants were immunoprecipitated overnight at $4{ }^{\circ} \mathrm{C}$ with anti-Akt/PKB antibody. The immunoprecipitates were collected on protein $\mathrm{A}$ Sepharose and washed. They were then incubated for $30 \mathrm{~min}$ at $25^{\circ} \mathrm{C}$ in $40 \mu \mathrm{L}$ of a reaction mix consisting of kinase buffer to which had been added $100 \mu \mathrm{M}(\gamma$ $\left.{ }^{32} \mathrm{P}\right)$ ATP $(10 \mu \mathrm{Ci} /$ Sample) and $30 \mu \mathrm{M}$ crosstide (Upstate Biotechnology). The reaction was stopped by spotting $5 \mu \mathrm{L}$ of the mix on P81 phosphocellulose paper (Whatman) followed by $3 \times 15$ min washing with $1 \% \mathrm{H}_{3} \mathrm{PO}_{4}$. The papers were dried, and the radioactivity was determined by exposure to BAS 2000 film (Fuji-Film, Tokyo, Japan). To investigate the inhibitory effects of PKC $\zeta$ on PKB activity in skeletal muscle PM of glucose-infused rats after 5 or 15 days, PM fraction were incubated with $25 \mu \mathrm{M}$ PS $\zeta$ for an hour and PKB activity was measured as aforementioned.

\section{Protein kinase expression and translocation}

Thirty microgram aliquots from the cytosolic and particulate fraction were used in the determination of PKC $\zeta$ expression and translocation. Aliquots (30-50 $\mu \mathrm{g})$ of homogenate prepared for the PI 3-kinase assay were used for the determination of PI 3-kinase-p85, PDK1, $\mathrm{PKC} \zeta$ and $\mathrm{PKB}$ concentrations. Proteins were subjected to western blots using enhanced chemiluminescence Plus, as described previously [35]. The intensity (area $\times$ density) of the individual bands on Western blots was measured by densitometry (model GS-700, Imaging Densitometer; Bio-Rad). The background was subtracted from the calculated area.

\section{PDK1-PKB reaction and $P K C \zeta-P K B$ association in the PM}

Immunoprecipitation was used for the isolation of PDK1 and $\mathrm{PKC} \zeta$. The protein concentrations of the membrane fractions (separated as described above) were measured and diluted with buffer to $10 \mu \mathrm{g}$ protein/ $\mu \mathrm{L}$. Then $100 \mu \mathrm{L}$ of the latter dilution were added to $10 \mu \mathrm{L}$ Protein A Sepharose and $10 \mu \mathrm{L}$ Sepharose and mixed. Anti-PDK1 or $-\mathrm{PKC} \zeta$-antibodies $(5 \mu \mathrm{g})$ were added and incubated overnight at $4^{\circ} \mathrm{C}$. Beads were then centrifuged at 
$500 \mathrm{rpm}$ for $1 \mathrm{~min}$. The pellet was washed three times and resuspended in $20 \mu \mathrm{L}$ washing buffer. Eventually, Laemmli buffer was added and cups were heated at $98^{\circ} \mathrm{C}$ for $10 \mathrm{~min}$. Supernatants were then quantitatively transferred to sodium dodecyl sulfate-polyacrylamide gel electrophoresis (7.5 or $10 \%$ acrylamide), separated and detected as described above. PDK1-PKB reactions and $\mathrm{PKC} \zeta-\mathrm{PKB}$ associations were determined using the antiAkt/PKB -antibody.

\section{GLUT $_{\mathbf{4}}$ translocation in skeletal muscle}

After $5 \mathrm{~d}$ or $15 \mathrm{~d}$ of GI, GLUT 4 translocation in skeletal muscle was measured using the method of Douen et al. [36].

\section{Statistical analysis}

All data are expressed as means \pm standard error of the mean. Data were analysed using unpaired Student's $t$ tests for the comparison of mean values. Data are also expressed as percentages of control animals. $p<0.05$ was considered statistically significant.

The authors have full access to the data and take full responsibility for the integrity of the data. All authors have read and agree to the manuscript as written.

\section{Results}

\section{Metabolic effects of continuous GI}

Continuous GI for 10 days induced transient hyperglycaemia and persistent hyperinsulinaemia (Figure 1A). Hyperglycaemia peaked after $24 \mathrm{~h}$ of GI. Despite further continuous GI, plasma glucose concentrations returned to normal values on the fifth day compared with controls. Plasma glucose concentrations in rats receiving continuous GI was high relative to that in the control rats on the tenth day, but the difference did not reach statistic significance. Serum insulin concentration increased $\sim 20$-fold after one day of GI, declined thereafter but remained significantly elevated up to the tenth day as compared to the control. Saline infusion affected neither plasma glucose nor insulin concentrations in control rats (Figure 1A). Serum insulin concentration recovered to normal and the plasma glucose increased in glucose-infused rats by the fifteenth day. Thus in this model the rats accommodated to systemic glucose oversupply and developed insulin resistance before the tenth day and type 2 diabetes by the fifteenth day. Because the metabolism of the rats changed from normoglycaemic/hyperinsulinaemic on day 5 to hyperglycaemic/normoinsulinaemic on day 15 , subsequent studies were focused on these two time points. Variations of body weight were presented in Figure 1B. There was a general tendency for the animals to gain weight with increasing length of infusion of either type, this was significant on day 5 of infusion. The animals gradually lost weight after day 5 . The body weight in glucose-infused rats significantly reduced by day 15 as compared with day 0 of the same group or compared with the saline-infused controls at day 15 .

\section{In vivo effects of GI on PI 3-kinase expression and activity}

Earlier studies with this model show that continuous GI induces increased glucose metabolism and insulin resistance in rat skeletal muscle [37-39]. Here, protein levels of the downstream signalling proteins IRS-1, PI 3-kinase-p85 was not affected, and no significant
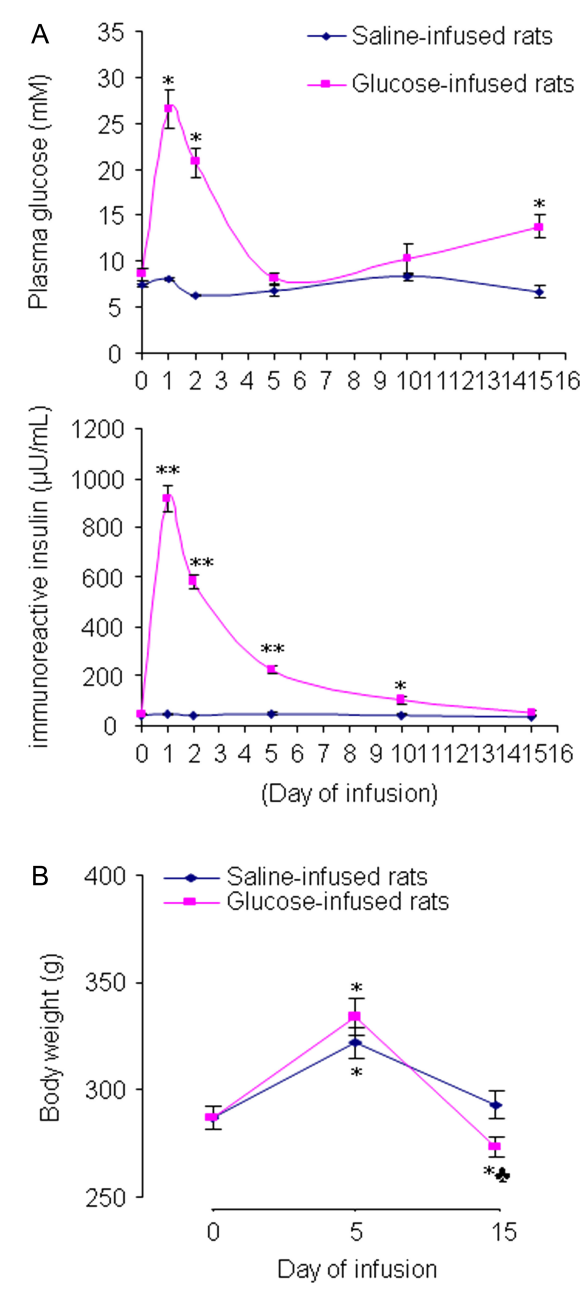

Figure 1. Effect of glucose infusion on plasma glucose, insulin concentrations and body weight. (A) The rats were treated with glucose infusion with the indicated time as described in Methods. Glucose and saline infusions were carried out at the same time. Blood samples were taken from the tail vein and glucose and insulin concentrations were determined as described in Methods. Data representing results of six independent experiments are expressed as means \pm standard error of the mean. ${ }^{*} p<0.05 ;{ }^{* *} p<0.01$ glucose infusion verus corresponding control rats. (B) Values are shown as means \pm standard error of the mean. ${ }^{*} p<0.05$ verus Day $0 ; \$ p<0.05$ verus saline-infused animals. This figure is available in colour online at www.interscience.wiley.com/journal/dmrr 
increases in basal IRS-1-associated PI 3-kinase activity and total phosphotyrosine-dependent PI 3-kinase activity were found in glucose-infused rats (Figure 2). Compared with control rats, rats exhibited a reduced response to insulin after either 5 or 15 days of GI. After insulin stimulation the IRS-1-associated PI 3-kinase activity and total phosphotyrosine-dependent PI 3-kinase activity of glucose-infused rats after 5 days and especially after 15 days were reduced significantly compared with control animals. Because activation of PI 3-kinase has been shown to be an essential step in insulin-dependent stimulation of glucose transport, these data show that the insulin resistance in this model can be traced down to the molecular level.

\section{In vivo effects of GI on PDK1 protein production and activity}

GI for five days significantly increased basal PDK1 activity about twofold (Figure 2D, E), but did not affect PDK1 protein expression. However, PDK1 activity was significantly lower in glucose-infused rats on day 15 than on day 5. Continuous saline infusion did not alter PDK1 activity or expression in control rats.

\section{In vivo effects of GI on overall PKC $\zeta$ protein levels and activity}

To delineate the mechanism by which continuous changes in the extracellular glucose concentration might contribute directly to insulin resistance and diabetes, we determined PKC $\zeta$ protein levels and activity in rat skeletal muscle after 5 and 15 days of GI. GI did not affect PKC $\zeta$ protein levels (Figure 3A), but significantly increased basal PKC $\zeta$ activity about twofold (Figure 3B) after 5 days. The PKC $\zeta$ activity significantly decreased and was lower than that in the control rats at day 15 of continued GI. To elucidate which fraction is responsible for the increased PKC $\zeta$ activity at day 5 infusion, we detected PKC $\zeta$ activity in PM and cytosolic fraction. As indicated in Figure 3C, five days of GI resulted in dramatic increase of PKC $\zeta$ activity in the cytosolic instead of PM
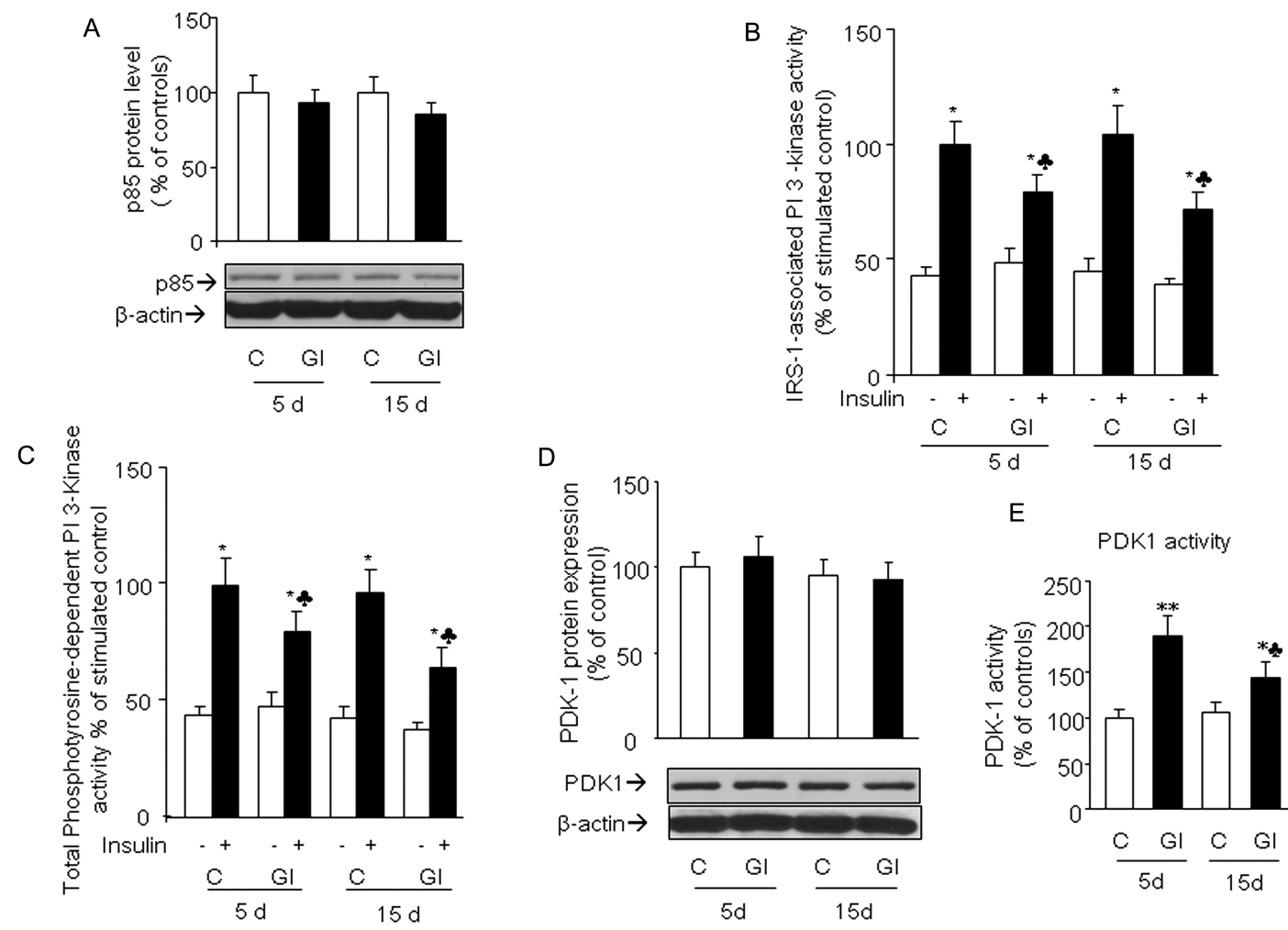

Figure 2. Total p85, phosphatidylinositol 3-kinase (PI 3-kinase) activity associated with insulin receptor substrate (IRS)-1 and total PI 3-kinase activity, PDK1 protein and activity in the skeletal muscle of control and glucose-infused rats. Homogenates were prepared from glucose-infused (GI) and control (C) rats and western blotting was performed to detect the p85 and PDK1. Protein, immunoprecipitated with anti-IRS-1 or anti-phosphotyrosine antibody, was subjected to sodium dodecyl sulfate-polyacrylamide gel electrophoresis followed by immunoblotting with anti-p85 antibody and determination of IRS-1-dependent PI 3-kinase activity and total PI 3-kinase activity. The other protein was immunoprecipitated with anti-PDK-1 antibody and subjected to determination of PDK1 activity as described in the Materials and Methods. (A) Representative immunoblot analysis showing p85 content (top) and quantification (bottom) of $\mathrm{p} 85$ protein levels by scanning densitometry. (B) PI 3-kinase activity associated with IRS-1. (C) Total PI 3-kinase activity. Data shown are means \pm standard error of the means of four independent experiments. Values are expressed as percentages of controls. ${ }^{*} P<0.05$ basal verus insulin-stimulated conditions; $\$, p<0.05$ verus corresponding control rats. (D) Representative immunoblot analysis showing the presence of PDK1 (top) and quantification (bottom) of PDK1 protein levels by scanning densitometry. (E) PDK1 activity. Data shown are means \pm standard error of the means of four independent experiments. Values are expressed as percentages of controls. ${ }^{*} p<0.05 ;{ }^{* *} p<0.01$ verus controls, $\stackrel{\infty}{\infty} p<0.05$ verus GI on day 5 
fraction, suggesting that $\mathrm{PKC} \zeta$ is primarily activated in the cytosol after glucose challenge.

\section{Effects of PS $\zeta$ or SH-6 on 2-DOG uptake in skeletal muscle of glucose-infused rats after 5 days}

As shown in Figure 3D, the basal 2-DOG uptake dramatically elevated (approximately threefold) and maximally insulin-stimulated rates of 2-DOG uptake was impaired in 5 days of glucose-infused rats compared with saline-infused rats. To gain more insight into the mechanism of glucose transport in insulin-resistant state, we measured 2-DOG uptake in skeletal muscle pretreated with myristoylated $\mathrm{PKC} \zeta$ peptide inhibitor (PS $\zeta$ ) or SH-6, a specific inhibitor of Akt/PKB in 5 days of glucoseinfused rats. 2-DOG uptake in skeletal muscle was reduced by $78 \%$ and $66 \%(p<0.05)$, respectively, in $\mathrm{PS} \zeta$ treated basal and insulin-stimulated groups compared with their corresponding non-treated groups. However, 2 -DOG uptake was reduced by $19 \%$ and $18 \%(p<0.05)$,

A
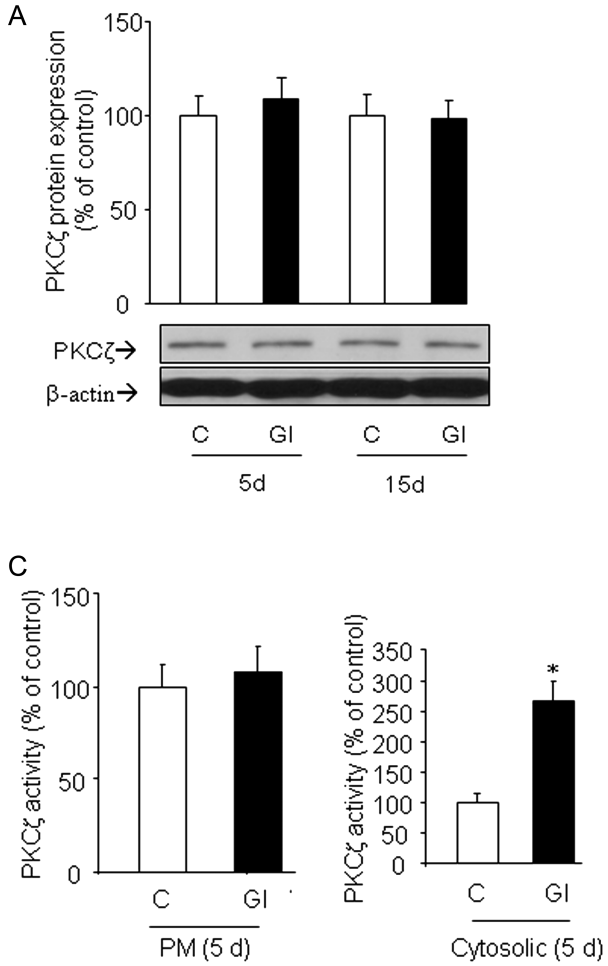

respectively, in SH-6-treated basal and insulin-stimulated groups compared with their corresponding non-treated groups. Combination of PS $\zeta$ and SH- 6 treatment caused a dramatic reduction of 2-DOG uptake, to a level of $10 \%$ of the values in non-treated groups both in basal and insulinstimulated muscle (Figure 3D). These data suggest that $\mathrm{PKC} \zeta$ may be mainly responsible for glucose transport in skeletal muscle in insulin-resistant state. In addition, as indicated in Figure 3D, 2-DOG uptake was dramatically impaired at day 15 of GI relative to day 5 .

\section{The translocation of PKC $\zeta$}

High glucose is known to activate PKC isoforms, which inhibit insulin signalling and stimulate GLUT4 translocation. Therefore, the cellular localization of the PKC $\zeta$ isoform was studied to assess possible activation under these experimental metabolic conditions. An increase in $\mathrm{PKC} \zeta$ protein content was seen in the cytosolic fractions after five days of GI, although it did not reach statistical significance (Figure 4). However, the activated
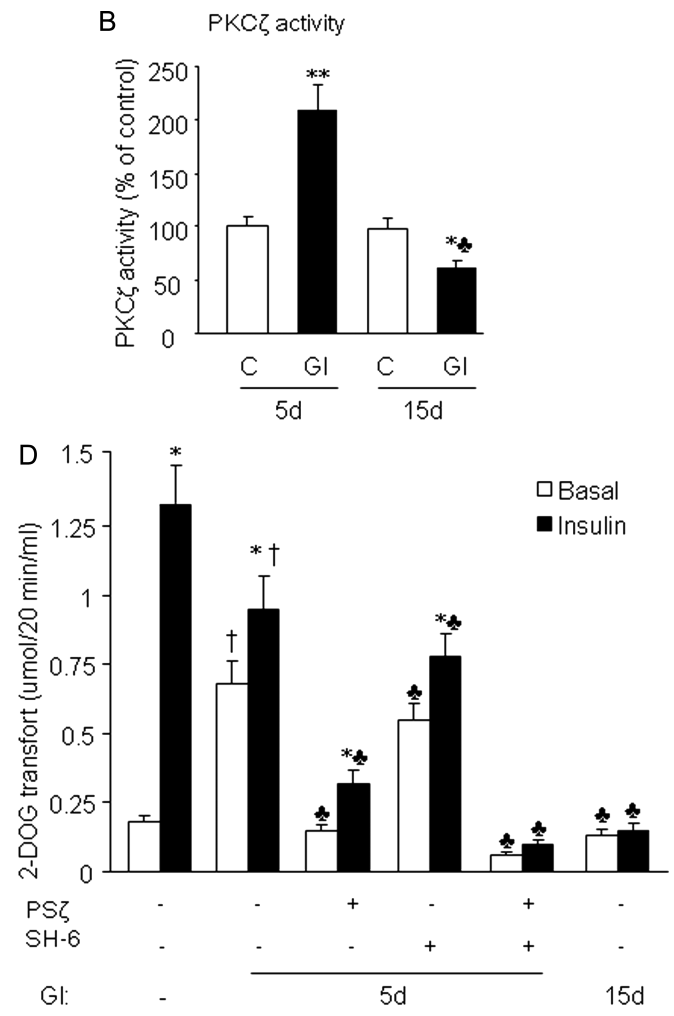

Figure 3. The active $\mathrm{PKC} \zeta$, which is mainly located in cytosol after glucose challenge, is responsible for glucose transport in skeletal muscle in insulin-resistant state. Homogenates were prepared from glucose infused (GI) and control (C) rats and western blotting was performed to detect the PKC $\zeta$ protein. Protein was immunoprecipitated with anti-PKC $\zeta$ antibody coupled to protein A/G Sepharose and subjected to determination of PKC $\zeta$ activity as described in the Materials and Methods. (A) Representative immunoblot analysis showing PKC $\zeta$ presence (top) and quantification (bottom) of PKC $\zeta$ protein levels by scanning densitometry. (B) PKC $\zeta$ activity. Data shown are means \pm standard error of the means of four independent experiments. Values are expressed as percentages of controls. ${ }^{*} p<0.05 ;{ }^{* *} p<0.01$ verus corresponding controls, $\$, p<0.05$ verus GI on day 5 . (C) PKC $\zeta$ activity in plasma membrane and cytosolic fraction. $n=3$; $^{*} p<0.05$ verus control group. (D) Effects of PS $\zeta$ or SH-6 on 2-DOG uptake in skeletal muscle of glucose-infused rats. The soleus muscles were removed and incubated in the presence or absence of myristoylated PKC $\zeta$ peptide inhibitor (PS $\zeta)(40 \mu \mathrm{M})$ or SH-6 (5 M), an inhibitor of Akt (PKB) for $1 \mathrm{~h}$ prior to incubation under basal conditions or stimulation with insulin (13 nM). 2-deoxyglucose uptake was measured as described in 'Materials and Methods.' Values are the means \pm standard error of the means of four independent experiments. ${ }^{*}, p<0.05$ basal verus insulin-stimulated conditions; $\$$, $p<0.05$ verus non-treated groups on day $5 ; \dagger, p<0.05$ verus corresponding non-GI groups 
A

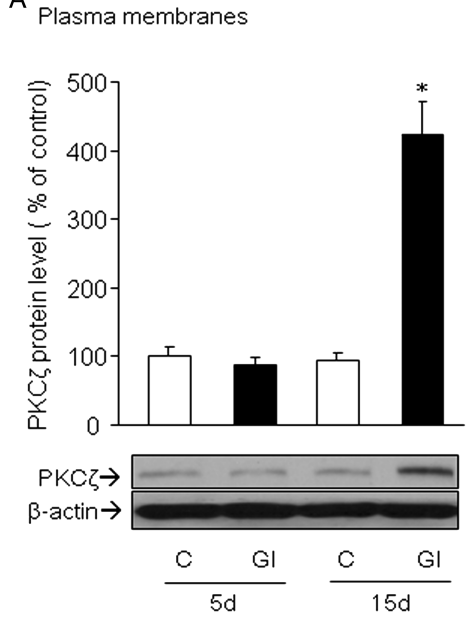

B

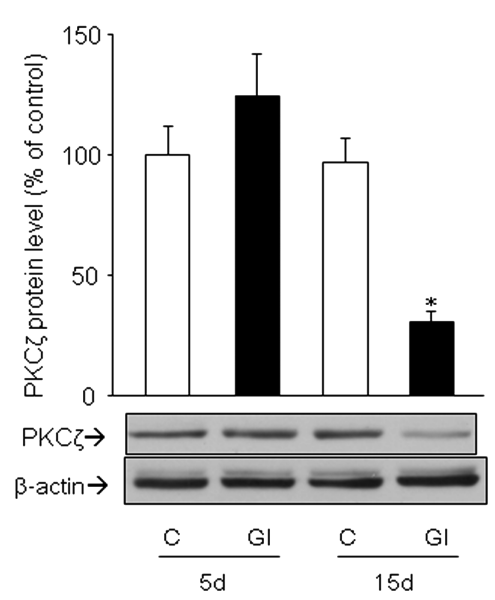

Figure 4. Effect of glucose infusion on the translocation of PKC $\zeta$ in rat skeletal muscle. Hind limb skeletal muscles were prepared from glucose-infused or saline-infused (C) rats and the plasma membrane and cytosol fractions were obtained as described in the Materials and Methods. Representative western blots indicating PKC $\zeta$ contents in plasma membrane (A) and cytosol fractions (B) are shown from a set of four independent experiments. The upper panels: Quantification of PKC $\zeta$ protein levels in plasma membranes and cytosol fractions by scanning densitometry. Data are shown as means \pm standard error of the means. Values are expressed as percentages of corresponding control values. ${ }^{*} p<0.05$ verus corresponding control rats

PKC $\zeta$ by GI is mainly located in the cytosol after five days of GI. Thereafter, PKC $\zeta$ was enriched in the PM after 15 days of GI and the corresponding cytosolic fractions were depleted (Figure 4). Quantitatively, GI caused more than fourfold enrichment of PKC $\zeta$ in the PM. Thus, continuous GI led to translocation of $\mathrm{PKC} \zeta$ from the cytosol to the PM.

\section{In vivo effects of GI on Akt/PKB content and activity}

The protein levels of Akt/PKB did not differ between the groups (Figure 5A). No significant increase in basal $\mathrm{PKB}$ activity was found in glucose-infused rats after five days, whereas it was reduced to about $44 \%$ of controls after 15 days (Figure 5B). In control rats, insulin administration resulted in a noticeable increase in $\mathrm{PKB}$ activity (Figure 5B). GI after 5 days and 15 days resulted in reduced response to insulin, and the activity of Akt/PKB after insulin stimulation was decreased by $22 \%$ and $56 \%$ $(p<0.05)$, respectively, compared with values measured in control rats.

\section{In vivo effects of GI on PDK1-PKB reaction and $P K C \zeta-P K B$ association at PM}

Binding studies have shown that $\mathrm{PKB}$ associates in vitro with the $\alpha, \delta$, and $\zeta$ isoforms of PKC [40]. We performed
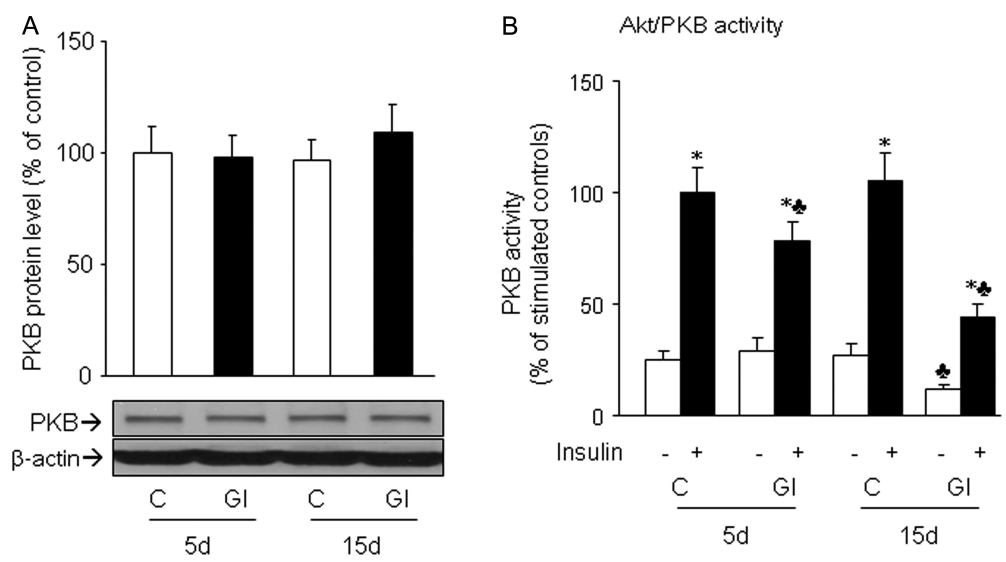

Figure 5. In vivo effects of GI on Akt/PKB protein content and activity in skeletal muscle of Wistar rats. The total lysate was subjected to sodium dodecyl sulfate-polyacrylamide gel electrophoresis followed by immunoblotting with anti-Akt/PKB antibody (A). An equal amount of muscle protein was immunoprecipitated with anti-Akt/PKB followed by determination of Akt/PKB activity (B). (A) representative immunoblot analysis showing Akt/PKB presence (bottom) and quantification (top) of Akt/PKB protein levels by scanning densitometry. (B) Akt/PKB activity in skeletal muscle. Data are shown as means \pm standard error of the means of three independent experiments. Values are expressed as percentages of controls. ${ }^{*}, p<0.05$ basal verus insulin-stimulated conditions; ڤ, $p<0.05$ verus corresponding control rats 
co-immunoprecipitation studies using PM fractions of skeletal muscle to investigate the possible interactions of PKC $\zeta$ as well as PDK1 with PKB in vivo. Endogenous PDK1 and $\mathrm{PKC} \zeta$ were immunoprecipitated from membrane fractions. $\mathrm{PKB}$ was detected in the $\mathrm{PKC} \zeta$ and PDK1 immunoprecipitates using western blotting (Figure 6A, B). The amounts of PDK1-PKB reactions and PKC $\zeta-\mathrm{PKB}$ associations at PM were not different between the control rats and glucose-infused rats after five days of GI. Interestingly, GI for 15 days led to a significant threefold increase in $\mathrm{PKC} \zeta-\mathrm{PKB}$ association at the $\mathrm{PM}$, whereas at the same time, the PDK1-PKB reaction was reduced to approximate $40 \%$ of the controls (Figure 6A, B). These results clearly demonstrate that the association between $\mathrm{PKC} \zeta$ and $\mathrm{PKB}$ is negatively correlated with PDK1-PKB reactions at the $\mathrm{PM}$. We propose that this demonstrates competitive inhibition.

\section{Effects of PS $\zeta$ on PKB activity in skeletal muscle PM of glucose-infused rats}

To confirm whether or not PKC $\zeta$ inhibited $\mathrm{PKB}$ activity after its membrane translocation, PM fraction of glucoseinfused rats after 5 or 15 days were isolated and incubated with $25 \mu \mathrm{M}$ PS $\zeta$ for an hour and PKB activity was measured. The specific $\mathrm{PKC} \zeta$ inhibitor, $\mathrm{PS} \zeta$, was used to selectively inhibit $\mathrm{PKC} \zeta$ activity. $\mathrm{PKB}$ activity in cytosol fraction could not be detected. PS $\zeta$ did not alter $\mathrm{PKB}$ activity in PM of saline-infused rats (data not shown). Basal and insulin-induced PKB activity in PM was significantly lower in glucose-infused rats on day 15 than on day 5. As expected, basal and insulininduced PKB activity in PM was considerably increased after PS $\zeta$ treatment in glucose-infused rats on day 15 when compared with non-treated groups (Figure 6C). It is logical to speculate that the inhibition of PKB activity might, at least partly, attribute to PKC $\zeta$ in PM. Taken together, these data show for the first time in skeletal muscle that $\mathrm{PKC} \zeta$ can inhibit $\mathrm{PKB}$ after translocation to PM.

\section{In vivo effects of GI on GLUT4 translocation in skeletal muscle}

GLUT4 protein levels were similar between control and glucose-infused rats (data not shown). GI for 5 days significantly increased GLUT4 protein levels in the PM but decreased the amount of GLUT4 protein in the lowdensity microsome fractions (Figure 7A, B), suggesting that glucose oversupply alone could contribute to increase in basal GLUT4 translocation at day 5. The insulinstimulated translocation of GLUT4 from the low-density microsome to the PM fractions in skeletal muscle was blunted progressively from 5 days to 15 days of GI (Figure 7A, B).

\section{Discussion}

Hyperglycaemia impaires insulin signalling, but the underlying mechanism is not fully understood [41]. To address the molecular mechanisms underlying glucoseinduced insulin resistance and diabetes, we employed the glucose-infused rat model. Inadequate pancreatic $\beta$-cell function is an essential component of all forms of diabetes. In our animal model, rats accommodating systemic glucose oversupply developed insulin resistance after 5 and 15 days, which can be traced down to the molecular level. Compared with control rats, rats exhibited a reduced response to insulin after either 5 or 15 days of GI. The insulin-stimulated IRS-1associated PI_3-kinase activity and total phosphotyrosinedependent PI 3-kinase activity (Figure 2B, C), insulinstimulated DOG-uptake (Figure 3D), insulin-stimulated PKB activity (Figure 5B) and insulin-stimulated GLUT4 PM-expression (Figure 7B) were reduced significantly compared with control animals, clearly indicating insulin resistance at the level of muscle. To maintain glucose homeostasis, $\beta$-cells increase insulin secretion and release, and the resulting enhanced insulin concentrations can compensate for insulin resistance. With the development of insulin resistance, $\beta$-cell exhaustion occurs by depletion of the readily releasable pool of intracellular insulin following prolonged exposure to a secretagogue [42]. After prolonged exposure to elevated glucose, pancreatic $\beta$-cell function is progressively and irreversibly impaired by chronic hyperglycaemia and over secretion. This detrimental effect is referred to as 'glucotoxicity' [43]. At this point, $\beta$-cells decompensate and reduce insulin secretion, so hyperglycaemia and overt diabetes emerge, which was shown in our animal model after 15 days of GI (hyperglycaemia/normoinsulinaemia). In addition to inducing functional changes, chronic hyperglycaemia can also decrease $\beta$-cell mass by inducing apoptosis [44].

A novel mechanistic finding of the current study is that the normalization of blood glucose concentration in insulin resistance state was mediated at least partially by an increased translocation of the GLUT4 protein to the $\mathrm{PM}$ of skeletal muscle. The insulin-signalling transduction on day 5 , as assessed by the determination of protein amounts and basal activities of PI 3-kinase and PKB, was not further increased when compared to control rats. PI 3-kinase activity and PKB/Akt activity after stimulation with exogenous insulin were impaired in skeletal muscle of glucose-infused rats after five days. Furthermore, the effect of glucose on PKC $\zeta$ was independent of changes in PI 3-kinase activity, and occurred in parallel with an increase in PDK1 activity. Our findings are consistent with an earlier report of Steiler et al. that basal PKC $\zeta$ activity was increased under hyperglycaemic conditions in Goto-Kakizaki and Wistar rats [45]. This finding of increased PKC $\zeta$ activity was confirmed in vitro in isolated soleus muscle exposed to high extracellular glucose, and occurred concomitant with an increase in 


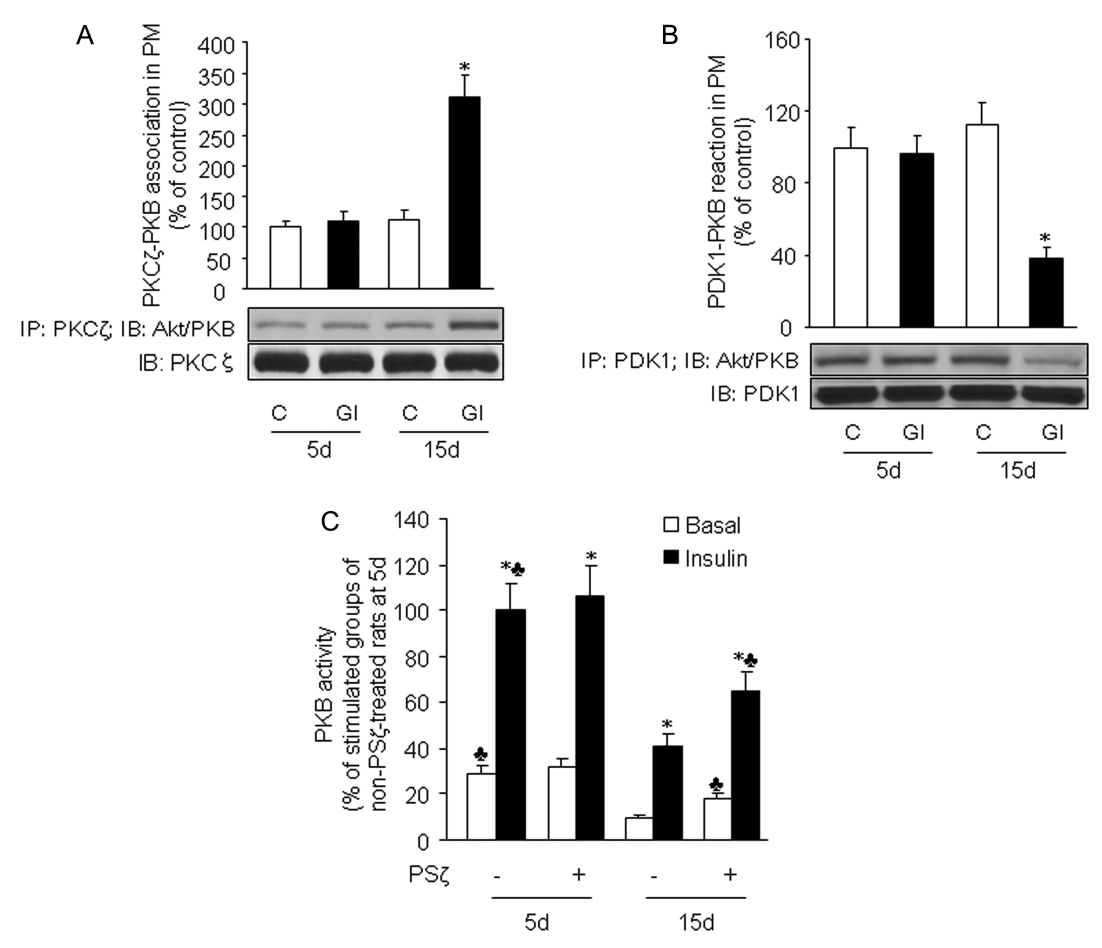

Figure 6. The translocation of PKC $\zeta$ to plasma membrane after 15 days of GI increases PKC $\zeta$-PKB association and inhibits PKB activity. The membrane fractions of skeletal muscle were prepared and incubated with antibodies against PDK1 or PKC $\zeta$ as described in the Materials and Methods. Immunoprecipitates were analysed for the presence of PKB by western blotting using anti-Akt/PKB monoclonal antibody. (A) Representative immunoblot analysis showing PKC $\zeta-\mathrm{PKB}$ association (top) and quantification (bottom) of PKC $\zeta$ - PKB associated protein levels by scanning densitometry. (B) Representative immunoblot analysis indicating PDK1-PKB reactions (top) and quantification (bottom) of PDK1-PKB associated protein levels by scanning densitometry. Data shown are means \pm standard error of the means of three independent experiments. Values are expressed as percentages of controls. ${ }^{* *} p<0.01$ verus corresponding control rats. C, Effects of PS $\zeta$ on PKB activity in skeletal muscle plasma membrane of glucose-infused rats. Plasma membrane fraction of glucose-infused rats after five or 15 days were isolated and incubated with $25 \mu \mathrm{M}$ PS $\zeta$ for an hour and PKB activity was measured as described in 'Materials and Methods.' Data shown are means \pm standard error of the means of four independent experiments. Values are expressed as percentages of insulin-stimulated groups of non-PS $\zeta$-treated plasma membrane of glucose-infused rats after 5 days. ${ }^{*}, p<0.05$ basal verus insulin-stimulated conditions; 2 , $p<0.05$ verus non-PS $\zeta$-treated groups of glucose-infused rats after 15 days

PDK1 activity. Their study also authenticated that acute hyperglycaemia leads to a parallel increase in PDK-1 and PKC $\zeta$ phosphorylation/activity via a PI 3-kinase$\mathrm{PKB} /$ Akt-independent mechanism. Taken together, these data suggest that the concentration of glycaemia may directly regulate $\mathrm{PKC} \zeta$ activity in skeletal muscle. In the present study, when PKC $\zeta$ was inhibited using a specific inhibitor, PS $\zeta$, basal and insulin-induced 2-DOG uptake in skeletal muscle of glucose-infused rats after 5 days were reduced by $78 \%$ and $66 \%$, respectively. Thus, it is mainly $\mathrm{PKC} \zeta$ rather than PKB that leads to increases in translocation of GLUT4 to the PM of skeletal muscle, which maintains normoglycaemia in the insulin-resistant state.

PDK1 is a downstream target of PI 3-kinase that was first described as an activator of PKB/Akt [46] and was later shown to activate members of the AGC kinase superfamily including PKC $\zeta$ [47]. However, glucose increases activity of $\mathrm{PKC} \zeta$ rather than $\mathrm{PKB} / \mathrm{Akt}$ indicating the existence of a divergence in the effects of PDK1 on these downstream substrates in the insulin-resistant state. The intracellular location of the temporary complex formed by PDK1 and its substrates can determine substrate specificity. Studies in 3T3 L1 adipocytes, in which wild type or PM-targeted
PDK1 are overexpressed, show that full activation of $\mathrm{PKB} /$ Akt requires PDK1 translocation to the PM, whereas, PKC $\zeta$ can be fully activated independently of insulin by overproduction of wild-type cytosolic PDK1 [48]. Thus, differences in the intracellular compartmentalization of PDK1 may provide a mechanism for these divergent effects on PKB/Akt and PKC $\zeta$.

$\mathrm{PKC} \zeta$ was originally discovered as a unique $\mathrm{PKC}$ isotype [49]. To date in mammals, it is classified into the atypical PKC subfamily, based on its structural similarity to PKC $\lambda / \iota$. Here we have shown that activation of PDK1 and $\mathrm{PKC} \zeta$ can be regulated by changes in the extracellular glucose concentration. Intriguingly, the activated form of PKC $\zeta$ is found in the cytosol after five days of GI. These results provide proof of concept for the first time that when activated, PKC $\zeta$ mainly retains in the cytosol rather than immediately translocates. Given that 5 day of GI increases PKC $\zeta$ activity and glucose uptake, which is coincident with an increased GLUT4 translocation, we speculate that the activated $\mathrm{PKC} \zeta$ contributes to the translocation of GLUT4 to PM and maintenance of normoglycaemia. Taken together, this striking activation of PKC $\zeta$ in the cytosol seems to serve as a compensatory mechanism for maintaining glucose homeostasis in the 


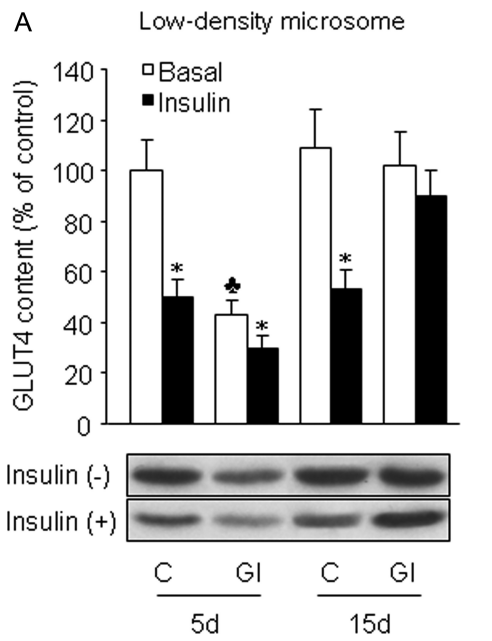

B Plasma membrane

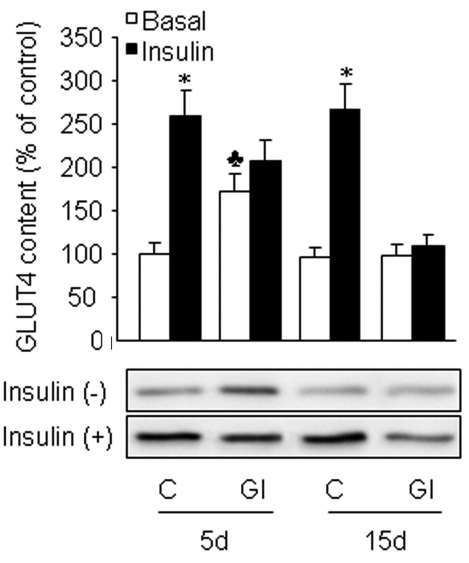

Figure 7. Effects of glucose-infusion on GLUT4 translocation in skeletal muscle tissues from Wistar rats. The plasma membrane and low-density microsome fractions isolated from skeletal muscles of saline-infused (C) or glucose-infused (GI) rats were subjected to sodium dodecyl sulfate-polyacrylamide gel electrophoresis followed by immunoblotting with anti-GLUT4 antibody. Representative immunoblot analyses showing GLUT4 protein levels (top) and quantified data (bottom) of GLUT4 protein in low-density microsome (A) and plasma membrane (B) fractions. Results are expressed as means \pm standard error of the means of three independent experiments. Values are expressed as percentages of controls. ${ }^{*} p<0.01$ verus basal groups; $\$ p<0.05$ verus control rats

insulin-resistant state. The insulin-signalling pathway on day 15 of GI, assessed by determination of the activities of PDK1, PKC $\zeta$, and PKB as well as translocation of GLUT4 to the PM, was decreased compared with those seen on day 5. A particularly notable aspect of the present studies was the translocation of $\mathrm{PKC} \zeta$ from the cytosol to PMs on day 15. With this move, the association of $\mathrm{PKC} \zeta$ with $\mathrm{PKB}$ is increased, accompanied by reduced reactions between PDK1 and $P K B$ in the membrane and inhibition of PKB activity. Our results suggest that $\mathrm{PKB}$ activity was impaired by $\mathrm{PKC} \zeta$ in $\mathrm{PM}$ (Figure 6). The combination of PKC $\zeta$ as well as PDK1 with $\mathrm{PKB}$ in PM demonstrates competitive inhibition. Therefore, we can not exclude the possibility that the inhibition of PKB activity is partly due to the decrease in reactions between PDK1 and PKB in the PM. In addition, the activity of $\mathrm{PKC} \zeta$ per se was compromised because of the increased association between $\mathrm{PKC} \zeta$ and $\mathrm{PKB}$. Whether $\mathrm{PKC} \zeta$ is directly inhibited by $\mathrm{PKB}$ at the $\mathrm{PM}$ remains to be determined. The reduced activity of PKC $\zeta$ and PKB leads to markedly blunted translocation of GLUT4 from low-density microsome to PM fractions in the skeletal muscle and eventual hyperglycaemia in rats with overt type 2 diabetes. Thus, it seems logical to assume that, when translocating to the PM, PKC $\zeta$ seems to serve primarily as a negative feedback inhibitor of glucose transport and maintain intracellular glucose homeostasis under normal physiological conditions. However, once the translocation is excessively activated, hyperglycaemia and overt diabetes will emerge. Thus, the long-term consequence of changed PDK1 and PKC $\zeta$ activity/localization should be considered in the context of diabetes mellitus.

In summary, we provide evidence that translocation of PKC $\zeta$ in skeletal muscle may play a vital role in the development of type 2 diabetes.

\section{Acknowledgements}

We thank Herman Rhee, $\mathrm{PhD}$ for valuable discussion and critical review of the manuscript. This work was supported by a grant (NO. 30370673) from National Natural Science Foundation of China and a grant (NO. 30113065) from the Educational Bureau of Hubei.

\section{Competing interests}

None declared.

\section{References}

1. Shepherd PR, Kahn BB. Glucose transporters and insulin action - implications for insulin resistance and diabetes mellitus. N Engl J Med 1999; 341: 248-257.

2. DeFronzo RA, Jacot E, Jequier E, Maeder E, Wahren J, Felber JP. The effect of insulin on the disposal of intravenous glucose. Results from indirect calorimetry and hepatic and femoral venous catheterization. Diabetes 1981; 30: 1000-1007.

3. Baron AD, Brechtel G, Wallace P, Edelman SV. Rates and tissue sites of non-insulin- and insulin-mediated glucose uptake in humans. Am J Physiol 1988; 255: E769-774.

4. Czech MP, Corvera S. Signaling mechanisms that regulate glucose transport. J Biol Chem 1999; 274: 1865-1868.

5. Zorzano A, Munoz P, Camps M, Mora C, Testar X, Palacin M. Insulin-induced redistribution of GLUT4 glucose carriers in the muscle fiber. In search of GLUT4 trafficking pathways. Diabetes 1996; 45: S70-81.

6. Garvey WT, Maianu L, Zhu JH, Brechtel-Hook G, Wallace P, Baron $\mathrm{AD}$. Evidence for defects in the trafficking and translocation of GLUT4 glucose transporters in skeletal muscle as a cause of human insulin resistance. $J$ Clin Invest 1998; 101: 2377-2386.

7. Ryder JW, Yang J, Galuska D, et al. Use of a novel impermeable biotinylated photolabeling reagent to assess insulin- and hypoxia-stimulated cell surface GLUT4 content in skeletal muscle from type 2 diabetic patients. Diabetes 2000; 49: 647-654.

8. Backer JM, Myers MG Jr, Shoelson SE, et al. Phosphatidylinositol $3^{\prime}$-kinase is activated by association with IRS-1 during insulin stimulation. Embo J 1992; 11: 3469-3479. 
9. Pessin JE, Saltiel AR. Signaling pathways in insulin action: molecular targets of insulin resistance. J Clin Invest 2000; 106: $165-169$.

10. Martin SS, Haruta T, Morris AJ, Klippel A, Williams LT, Olefsky JM. Activated phosphatidylinositol 3-kinase is sufficient to mediate actin rearrangement and GLUT4 translocation in 3T3-L1 adipocytes. $J$ Biol Chem 1996; 271: 17605-17608.

11. Wang Q, Somwar R, Bilan PJ, et al. Protein kinase B/Akt participates in GLUT4 translocation by insulin in L6 myoblasts. Mol Cell Biol 1999; 19: 4008-4018.

12. Bandyopadhyay G, Standaert ML, Zhao L, et al. Activation of protein kinase C (alpha, beta, and zeta) by insulin in 3T3/L1 cells. Transfection studies suggest a role for PKC-zeta in glucose transport. J Biol Chem 1997; 272: 2551-2558.

13. Kralik SF, Liu P, Leffler BJ, Elmendorf JS. Ceramide and glucosamine antagonism of alternate signaling pathways regulating insulin- and osmotic shock-induced glucose transporter 4 translocation. Endocrinology 2002; 143: 37-46.

14. Chen D, Elmendorf JS, Olson AL, Li X, Earp HS, Pessin JE. Osmotic shock stimulates GLUT4 translocation in 3T3L1 adipocytes by a novel tyrosine kinase pathway. $J$ Biol Chem 1997; 272: 27401-27410.

15. Yki-Jarvinen H, Helve E, Koivisto VA. Hyperglycemia decreases glucose uptake in type I diabetes. Diabetes 1987; 36: 892-896.

16. Zierath JR, Galuska D, Nolte LA, Thorne A, Kristensen JS Wallberg-Henriksson H. Effects of glycaemia on glucose transport in isolated skeletal muscle from patients with NIDDM: in vitro reversal of muscular insulin resistance. Diabetologia 1994; 37: 270-277.

17. Krook A, Kawano Y, Song XM, et al. Improved glucose tolerance restores insulin-stimulated Akt kinase activity and glucose transport in skeletal muscle from diabetic Goto-Kakizaki rats. Diabetes 1997; 46: 2110-2114.

18. Nawano M, Oku A, Ueta K, et al. Hyperglycemia contributes insulin resistance in hepatic and adipose tissue but not skeletal muscle of ZDF rats. Am J Physiol Endocrinol Metab 2000; 278: E535-543.

19. Nawano M, Ueta K, Oku A, et al. Hyperglycemia impairs the insulin signaling step between PI 3-kinase and Akt/PKB activations in ZDF rat liver. Biochem Biophys Res Commun 1999; 266: 252-256.

20. Kurowski TG, Lin Y, Luo Z, et al. Hyperglycemia inhibits insulin activation of Akt/protein kinase B but not phosphatidylinositol 3-kinase in rat skeletal muscle. Diabetes 1999; 48: 658-663.

21. Song XM, Kawano Y, Krook A, et al. Muscle fiber type-specific defects in insulin signal transduction to glucose transport in diabetic GK rats. Diabetes 1999; 48: 664-670.

22. Yki-Jarvinen $H$, Makimattila S. Insulin resistance due to hyperglycaemia: an adaptation protecting insulin-sensitive tissues. Diabetologia 1997; 40: S141-144.

23. Galante P, Mosthaf L, Kellerer M, et al. Acute hyperglycemia provides an insulin-independent inducer for GLUT4 translocation in $\mathrm{C} 2 \mathrm{C} 12$ myotubes and rat skeletal muscle. Diabetes 1995; 44: 646-651.

24. Berti L, Mosthaf L, Kroder G, et al. Glucose-induced translocation of protein kinase $\mathrm{C}$ isoforms in rat-1 fibroblasts is paralleled by inhibition of the insulin receptor tyrosine kinase. $J$ Biol Chem 1994; 269: 3381-3386.

25. Doornbos RP, Theelen M, van der Hoeven PC, van Blitterswijk WJ, Verkleij AJ, van Bergen en Henegouwen PM. Protein kinase Czeta is a negative regulator of protein kinase $B$ activity. J Biol Chem 1999; 274: 8589-8596.

26. Leahy JL, Cooper HE, Weir GC. Impaired insulin secretion associated with near normoglycemia. Study in normal rats with 96-h in vivo glucose infusions. Diabetes 1987; 36: 459-464.

27. Ammon HP, Bacher M, Brandle WF, et al. Effect of forty-eighthour glucose infusion into rats on islet ion fluxes, ATP/ADP ratio and redox ratios of pyridine nucleotides. $J$ Endocrinol 1998; 156: 583-590.

28. Houdali B, Nguyen V, Ammon HP, et al. Prolonged glucose infusion into conscious rats inhibits early steps in insulin signalling and induces translocation of GLUT4 and protein kinase C in skeletal muscle. Diabetologia 2002; 45: 356-368.

29. Henriksen EJ, Holloszy JO. Effect of diffusion distance on measurement of rat skeletal muscle glucose transport in vitro. Acta Physiol Scand 1991; 143: 381-386.

30. Young DA, Uhl JJ, Cartee GD, Holloszy JO. Activation of glucose transport in muscle by prolonged exposure to insulin. Effects of glucose and insulin concentrations. J Biol Chem 1986; 261: 16049-16053.

31. Itani SI, Zhou Q, Pories WJ, MacDonald KG, Dohm GL. Involvement of protein kinase $\mathrm{C}$ in human skeletal muscle insulin resistance and obesity. Diabetes 2000; 49: 1353-1358.

32. Anai M, Funaki M, Ogihara T, et al. Altered expression levels and impaired steps in the pathway to phosphatidylinositol 3-kinase activation via insulin receptor substrates 1 and 2 in Zucker fatty rats. Diabetes 1998; 47: 13-23.

33. Alessi DR, James SR, Downes CP, et al. Characterization of a 3-phosphoinositide-dependent protein kinase which phosphorylates and activates protein kinase Balpha. Curr Biol 1997; 7: 261-269.

34. Standaert ML, Galloway L, Karnam P, Bandyopadhyay G, Moscat J, Farese RV. Protein kinase C-zeta as a downstream effector of phosphatidylinositol 3-kinase during insulin stimulation in rat adipocytes. Potential role in glucose transport. J Biol Chem 1997; 272: 30075-30082

35. Davis BJ, Xie Z, Viollet B, Zou MH. Activation of the AMPactivated kinase by antidiabetes drug metformin stimulates nitric oxide synthesis in vivo by promoting the association of heat shock protein 90 and endothelial nitric oxide synthase. Diabetes 2006; 55: 496-505.

36. Douen AG, Ramlal T, Rastogi S, et al. Exercise induces recruitment of the "insulin-responsive glucose transporter". Evidence for distinct intracellular insulin- and exerciserecruitable transporter pools in skeletal muscle. $J$ Biol Chem 1990; 265: 13427-13430.

37. Hager SR, Jochen AL, Kalkhoff RK. Insulin resistance in normal rats infused with glucose for 72 h. Am J Physiol 1991; 260: E353-362.

38. Laybutt DR, Schmitz-Peiffer C, Saha AK, Ruderman NB, Biden TJ, Kraegen EW. Muscle lipid accumulation and protein kinase $\mathrm{C}$ activation in the insulin-resistant chronically glucoseinfused rat. Am J Physiol 1999; 277: E1070-1076.

39. Laybutt DR, Chisholm DJ, Kraegen EW. Specific adaptations in muscle and adipose tissue in response to chronic systemic glucose oversupply in rats. Am J Physiol 1997; 273: E1-9.

40. Konishi H, Kuroda S, Tanaka M, et al. Molecular cloning and characterization of a new member of the RAC protein kinase family: association of the pleckstrin homology domain of three types of RAC protein kinase with protein kinase $\mathrm{C}$ subspecies and beta gamma subunits of $\mathrm{G}$ proteins. Biochem Biophys Res Commun 1995; 216: 526-534.

41. Oku A, Nawano M, Ueta K, et al. Inhibitory effect of hyperglycemia on insulin-induced Akt/protein kinase B activation in skeletal muscle. Am J Physiol Endocrinol Metab 2001; 280: E816-824.

42. Leahy JL, Bumbalo LM, Chen C. Diazoxide causes recovery of beta-cell glucose responsiveness in 90\% pancreatectomized diabetic rats. Diabetes 1994; 43: 173-179.

43. Kaiser N, Leibowitz G, Nesher R. Glucotoxicity and beta-cell failure in type 2 diabetes mellitus. $J$ Pediatr Endocrinol Metab 2003; 16: 5-22.

44. Donath MY, Gross DJ, Cerasi E, Kaiser N. Hyperglycemiainduced beta-cell apoptosis in pancreatic islets of Psammomys obesus during development of diabetes. Diabetes 1999; 48: 738-744.

45. Steiler TL, Galuska D, Leng Y, Chibalin AV, Gilbert M, Zierath JR. Effect of hyperglycemia on signal transduction in skeletal muscle from diabetic Goto-Kakizaki rats. Endocrinology 2003; 144: 5259-5267.

46. Jensen CJ, Buch MB, Krag TO, Hemmings BA, Gammeltoft S, Frodin M. $90-\mathrm{kDa}$ ribosomal S6 kinase is phosphorylated and activated by 3 -phosphoinositide-dependent protein kinase-1. J Biol Chem 1999; 274: 27168-27176.

47. Stokoe D, Stephens LR, Copeland T, et al. Dual role of phosphatidylinositol-3,4,5-trisphosphate in the activation of protein kinase B. Science 1997; 277: 567-570.

48. Egawa K, Maegawa H, Shi K, et al. Membrane localization of 3-phosphoinositide-dependent protein kinase-1 stimulates activities of Akt and atypical protein kinase $\mathrm{C}$ but does not stimulate glucose transport and glycogen synthesis in 3T3-L1 adipocytes. J Biol Chem 2002; 277: 38863-38869.

49. Ono Y, Fujii T, Ogita K, Kikkawa U, Igarashi K, Nishizuka Y. Protein kinase $\mathrm{C}$ zeta subspecies from rat brain: its structure, expression, and properties. Proc Natl Acad Sci USA 1989; 86: 3099-3103. 